


JOURNAL

OF

SUSTAINABLE

MINING

Volume 19 | Issue 2

Article 3

2020

\title{
Alternative methodology to determine effective coefficient of methane diffusion in coal
}

Author(s) ORCID Identifier:

Henryk Koptoń (iD 0000-0002-5229-4798

Follow this and additional works at: https://jsm.gig.eu/journal-of-sustainable-mining

Part of the Explosives Engineering Commons, Oil, Gas, and Energy Commons, and the Sustainability

Commons

\section{Recommended Citation}

Koptoń, Henryk (2020) "Alternative methodology to determine effective coefficient of methane diffusion in coal," Journal of Sustainable Mining: Vol. 19 : Iss. 2 , Article 3.

Available at: https://doi.org/10.46873/2300-3960.1008

This Research Article is brought to you for free and open access by Journal of Sustainable Mining. It has been accepted for inclusion in Journal of Sustainable Mining by an authorized editor of Journal of Sustainable Mining. 


\title{
Alternative methodology to determine effective coefficient of methane diffusion in coal
}

\author{
Abstract \\ The article presents the results of research in to the development of an alternative method of determining \\ the effective coefficient of methane diffusion in coal, based on a mathematical model following Fick's \\ second law. The research was conducted based on the recorded courses of methane sorption kinetics in \\ coal samples obtained in laboratory conditions with the precise gravimetric sorption system IGA-001. The \\ value of the coefficient was treated as an element tuning the model in such a way that the average \\ relative error of the ex post was as small as possible. Model verification indicated the correctness of its \\ assumptions. The development of a more accurate methodology to determine the effective coefficient of \\ methane diffusion in coal will enable the verification of the models applied in order to describe the \\ physical and chemical mechanisms of the methane desorption natural phenomenon. It will also pave the \\ way for further research aimed at the determination of: the gas bearing capacity of coal seams, the \\ degree of degassing of seamswhich results from the mining operations being conducted; or to what \\ extent it is possible to degas the deposits.
}

\section{Keywords}

Mining; Coal; Sorption; Diffusion; Methane; Diffusion coefficient

\section{Creative Commons License}

(c) (1)

This work is licensed under a Creative Commons Attribution 4.0 License. 


\title{
Alternative methodology to determine effective coefficient of methane diffusion in coal
}

\author{
Henryk Koptoń
}

Experimental Mine "Barbara", Department of Gas Hazard Control, The Central Mining Institute (Katowice, Poland) ul. Podleska 72, 43190, Mikołów, Poland

\begin{abstract}
The article presents the results of research in to the development of an alternative method of determining the effective coefficient of methane diffusion in coal, based on a mathematical model following Fick's second law. The research was conducted based on the recorded courses of methane sorption kinetics in coal samples obtained in laboratory conditions with the precise gravimetric sorption system IGA-001. The value of the coefficient was treated as an element tuning the model in such a way that the average relative error of the ex post was as small as possible. Model verification indicated the correctness of its assumptions. The development of a more accurate methodology to determine the effective coefficient of methane diffusion in coal will enable the verification of the models applied in order to describe the physical and chemical mechanisms of the methane desorption natural phenomenon. It will also pave the way for further research aimed at the determination of: the gas bearing capacity of coal seams, the degree of degassing of seamswhich results from the mining operations being conducted; or to what extent it is possible to degas the deposits.
\end{abstract}

Keywords: mining, coal, sorption, diffusion, methane, diffusion coefficient

\section{Introduction}

M ining works conducted in a highly gassy deposit are accompanied by methane emissions into the mine workings, which may result in an explosion hazard. Hence, research into methane desorption from coal seams is still an important issue, both for the safety of the mine works and for environmental protection. Therefore, laboratory tests of methane sorption play an important role. They help the mechanism of the phenomenon of methane emission in nature to be recognized, the set of factors and parameters which influence its course to be determined and they provide input data for the models which determine methane emission into mine workings during mining operations. The research, which has been conducted at the Central Mining Institute in Katowice (Poland) since 2006, shows that when mining works are conducted in a gassy deposit, sorption properties of coal (methane sorption capacity and effective coefficient of methane diffusion in coal) significantly influence the level and character of methane emission [1-11]. Sorption properties of coal influence the level of gas and rocks outburst hazard [12]. Various types of coal demonstrate different sorption properties in given deposits. To characterise hard coals and their ability to accumulate and desorb methane, the tests conducted by Central Mining Institute, Department of Gas Hazard Control in the Barbara experimental mine determine sorption capacity of coal in standard conditions and the value of the effective coefficient of diffusion. The value of the effective coefficient of diffusion characterises the kinetics of methane sorption. The methodology of determining the coefficient was developed by Timofeev in the early 1960s [13]. The order of magnitude, which the coefficient reaches, often results in significant inaccuracy exceeding the acceptable error. Hence, the research makes an 
attempt to develop a new methodology with IT techniques.

\section{Currently applied methodology of determining the sorption properties of coal}

Tests of the sorption properties of hard coals which primarily focus on the gas and rock outburst hazard aspect are conducted by the Central Mining Institute in the laboratory of the Department of Gas Hazard Control in the Barbara experimental mine. Hiden Isochema's Intelligent Gravimetric Analyser IGA-001, a high accuracy gravimetric and sorption system for the precise analyses of gas sorption volume, dynamics and kinetics, was applied to determine the amount of gas accumulated through sorption, i.e. mainly the capacity of coal seams. It is advanced equipment which measures changes in the weight of a sample over time, caused by the sorption processes occurring in coal and other porous materials (Fig. 1). Sorption analysers, whose working principle is based on the gravimetric method, have been used for sorption and diffusion tests for just over a dozen or so years [14]. The advantages of this method of testing hard coals are presented by, among others, [15,16] and [17].

To characterise methane accumulation and the desorption of hard coals, the tests determined the sorption capacity of coal in standard conditions and the value of the effective coefficient of diffusion $[10,18,19]$. Standard sorption capacity $q_{s}$ was determined for a dry sample in laboratory conditions in $\mathrm{cm}^{3} / \mathrm{g}$ of methane sorbed by coal at the point of equilibrium which was reached under standard atmospheric pressure ( $1 \mathrm{bar})$ and temperature $\left(25^{\circ} \mathrm{C}\right.$, i.e. $298 \mathrm{~K})$. The test results are presented the in form of methane sorption kinetics graphs. This paper will analyse a methane sorption kinetics graph obtained in the tests of a coal sample collected in incline $\mathrm{N}-1$, seam 404/4 of the Pniówek coal mine in the Upper Silesian Coal Basin (Fig. 2).

The data recorded during the tests was applied to determine the value of the methane sorption capacity of the coal in standard conditions, as the amount of the methane sorbed at the point of equilibrium. Sorption capacity is expressed in $\mathrm{cm}^{3} /$ $\mathrm{g}$, thus, the value expressed in $\mathrm{mg} \mathrm{CH}_{4}$ /g ought to be divided by methane density in standard conditions. For the case above, methane sorption capacity was determined as

$q_{\mathrm{s}}=4,579 \mathrm{~cm}^{3} / \mathrm{g}$

Methane sorption kinetics is a very important factor in the assessment of the dynamics of methane emission from a coal seam, where (or in the vicinity

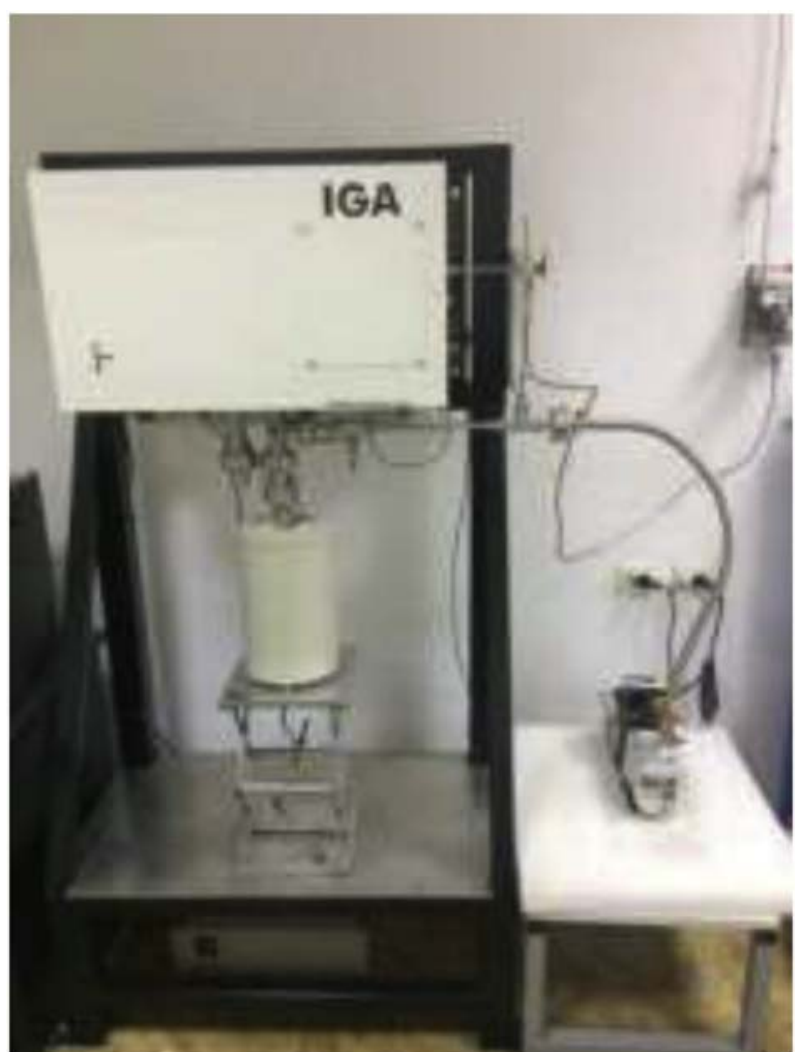

Fig.1. Gravimetric analyser IGA-001 to test gas sorption.

of which) mining works are conducted (roadways, longwalls) [2-6,10,20-24]. Methane sorption kinetics is characterised by the effective coefficient of methane diffusion in coal $D_{e}$, which is determined in laboratory conditions and expressed in $\mathrm{cm}^{2} / \mathrm{s}$. The value of the coefficient depends on the diffusion mechanism in the pores of the solid phase and properties of the system [25-27]. To determine the value [21], the time corresponding to the half-saturation of coal is read from the sorption kinetics graph and then substituted in Timofeev's equation, from the beginning of the 1960s [13,18]:

$D_{e}=\frac{0,308 \cdot R^{2}}{\pi^{2} t_{0,5}}$

where:

$D_{e}$ - effective coefficient of diffusion, $\mathrm{cm}^{2} / \mathrm{s}$,

$R$ - mean coal grain radius, $\mathrm{cm}$,

$t_{0,5}$ - time corresponding half-saturation of coal, $\mathrm{s}$.

Mean grain radius $R$ for laboratory conditions is calculated with the equation: 


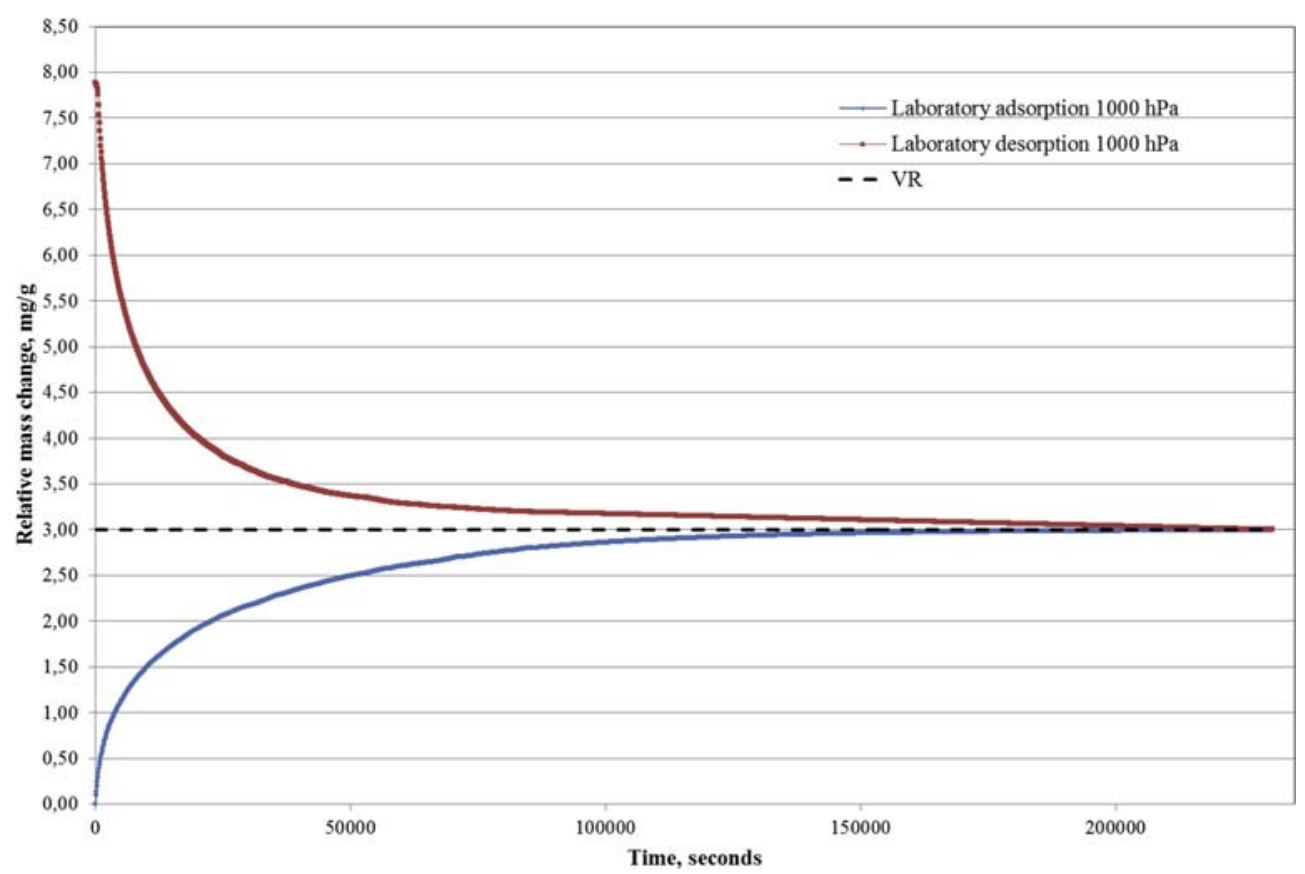

Fig.2. Methane sorption kinetics graph-coal sample of seam 404/4 in the Pniówek coal mine.

$R=\frac{1}{2} \sqrt[3]{\frac{2 d_{1}^{2} d_{2}^{2}}{d_{1}+d_{2}}}, \mathrm{~cm}$

where:

$R$ - mean radius of grain size, $\mathrm{cm}$,

$d_{1}-$ upper radius of grain size, $\mathrm{cm}$,

$d_{2}-$ lower radius of grain size, $\mathrm{cm}$.

The equation is a transformation of W. Budryk's equation [21]. For the analysed case, the value of the effective coefficient of methane diffusion in coal, calculated basing on equations (1) and (2), are $R=0.0179 \mathrm{~cm}$ and $t_{0,5}=10470 \mathrm{~s}, \quad$ is $D_{e}=$ $0.952 \cdot 10^{-9} \mathrm{~cm}^{2} / \mathrm{s}$.

As it previously mentioned in the introduction, applying such a method of determining the effective coefficient of diffusion often results in significant inaccuracies, which exceed acceptable error (most often of up to $25 \%$ ), and, as a consequence, renders it impossible to interpret properly its value to assessing methane hazard and methane and rock outburst hazard, and to carry out an accurate forecast of methane emissions into mine workings.

\section{Mathematical model describing the course} of methane sorption kinetics in coal samples-

\section{alternative methodology to determine the effective coefficient of diffusion}

The J.P. Seidel method, applied in the American mining industry, may be one of the methods used to illustrate the mechanism of methane desorption from coal $[22,28,29]$. Like other models (e.g. the uniporediffusion model - [30], the methodology tries to reflect the complex mechanism of methane emission from spherical grain $(0 \leq r \leq R)$, with effective coefficient of diffusion $D_{e}$, starting with the following equation:

$\frac{\partial V}{\partial t}=D_{e}\left(\frac{2}{r} \frac{\partial V}{\partial r}+\frac{\partial^{2} V}{\partial r^{2}}\right)$

It may be observed that equation (3) follows Fick's second law for isotropic radial diffusion, determining changes in the concentration of diffusing component (in this case - methane) over time, in the specific cross-section of the diffusion flux. For the equation, the initial condition looks as follows:

\section{$V(r, 0)=V_{0}($ initials gas content $)$}

And the boundary conditions ought to consider the variability of the amount of methane on the surface of a microporous grain over time:

$$
V(R, t)=V_{R}(t) ;\left.\frac{\partial V(r, t)}{\partial t}\right|_{r=0}=0
$$


The boundary value is often assumed to be constant $V_{R}=$ const (the target amount of gas which indicates the sorption capacity of coal in given conditions).

The solution of this issue, expressed with an infinite series after integrating the grain volume, looks as follows:

$\bar{V}(t)=\bar{V}_{\infty}\left[1-\frac{6}{\pi^{2}} \sum_{n=1}^{\infty} \frac{1}{n^{2}} \exp \left(-n^{2} \pi^{2} \frac{D_{e} t}{R^{2}}\right)\right]$

When $\bar{V}(t) / \bar{V}_{\infty}<0.25$, [31] concluded that for the time when $\left.\bar{V}(t) / \bar{V}_{\infty}<0.5\right)$ the equation above can be simplified to the following form:

$\bar{V}(t)=6 \bar{V}_{\infty} \sqrt{\frac{D_{e} t}{\pi R^{2}}}$

When $\bar{V}(t) / \bar{V}_{\infty}>0.7$, equation 6 only has to consider the first sum element $(n=1)$, hence:

$\bar{V}(t)=\bar{V}_{\infty}\left[1-\frac{6}{\pi^{2}} \exp \left(-\pi^{2} \frac{D_{e} t}{R^{2}}\right)\right]$

where:

$D e$ - value of the effective coefficient of methane diffusion in coal, $\mathrm{cm}^{2} / \mathrm{s}$,

$t$ - time, s.

$R$ - mean coal grain radius, $\mathrm{cm}$.

Equilibrium methane content in grains $\bar{V}_{\infty}$ corresponds to the infinitely long duration of this process. In the analysed case - in laboratory conditions, when the sorption curve is determined, equilibrium is reached after approximately one day. Clearly, in underground mine conditions, it would take much longer to reach equilibrium, perhaps even a few years depending on the grain radius $R$.

In the laboratory case, the equations are solved assuming a relative increase in the weight of methane in $\mathrm{mg} \mathrm{CH} / \mathrm{g}$. The values of the components of the equation are as follows:

$D_{e}=0.952 \cdot 10^{-9} \mathrm{~cm}^{2} / \mathrm{s}$

$\bar{V}_{\infty}=V_{r}=3.001 \mathrm{mg} \mathrm{CH} \mathrm{CH}_{4} / \mathrm{g}$, corresponding sorption capacity in standard conditions $q_{s}=4.579 \mathrm{~cm}^{3} / \mathrm{g}$,

$R=0.0179 \mathrm{~cm}$

After substituting the data in equations (7) and (8) and considering the time distribution $t$ obtained the during tests, the adsorption curve was obtained. The calculations are the ex post forecast of the increase in the weight of the methane obtained in the laboratory.

The indirect results of the test of sorption properties conducted with gravimetric system IGA-001, are automatically recorded in the computer using IGASwin software in the form of1. DAT files, which can then be converted and opened with Microsoft Excel. It must also be emphasised that the data recorded by gravimetric system IGA-001, in this case included 772 measurements of an increase in the weight of the methane.

The calculations will be conducted in two ways:

$>$ variant I - substituting the values of the effective coefficient of diffusion calculated according to Timofeev's equation, i.e. $D_{e}=0.952 \cdot 10^{-9} \mathrm{~cm}^{2} / \mathrm{s}$,

$>$ variant II - the value of coefficient $D_{e}$ is treated as an element tuning the model, substituting various values within the range which are similar to the value assumed in variant I and observing which value of $D_{e}$ results in the lowest value of mean relative forecast error $e x$ post $\Psi$; in order to simplify the process, the Microsoft Excel Solver add-in can be applied.

The calculations made according to variant II are also assumptions for the methodology of determining the effective coefficient of methane diffusion in coal which is an alternative to the methodology which uses the Timofeev equation.

Figs. 3 and 4 present the methane sorption (adsorption) kinetics curve for the analysed coal sample from coal seam 404/4 in the Pniówek coal mine, obtained with both the laboratory method and the computational method, after substituting data in equations (7) and (8) according to variant I and comparing the course of methane adsorption for the coal sample, obtained with the laboratory and analytical methods according to J. P. Seidle's model in the given variant.

The comparison shows that the value of the coefficient of determination $R^{2}=0.9956$, corresponding to Pearson's correlation coefficient $r=0.9978$, indicates nearly full correlation between the results recorded during the laboratory tests and the results obtained with the analytical method. The value of mean relative error is $\Psi=1.64 \%$.

Figs. 5 and 6 below present the curve of methane sorption kinetics (adsorption) for the tested coal sample from seam 404/4 of the Pniówek coal mine, obtained with the laboratory method and the computational method, after substituting data in equations (7) and (8) according to variant II; and the comparison between methane adsorption courses for a coal sample, obtained with the laboratory and analytical methods according to J.P. Seidle's model in the variant. 


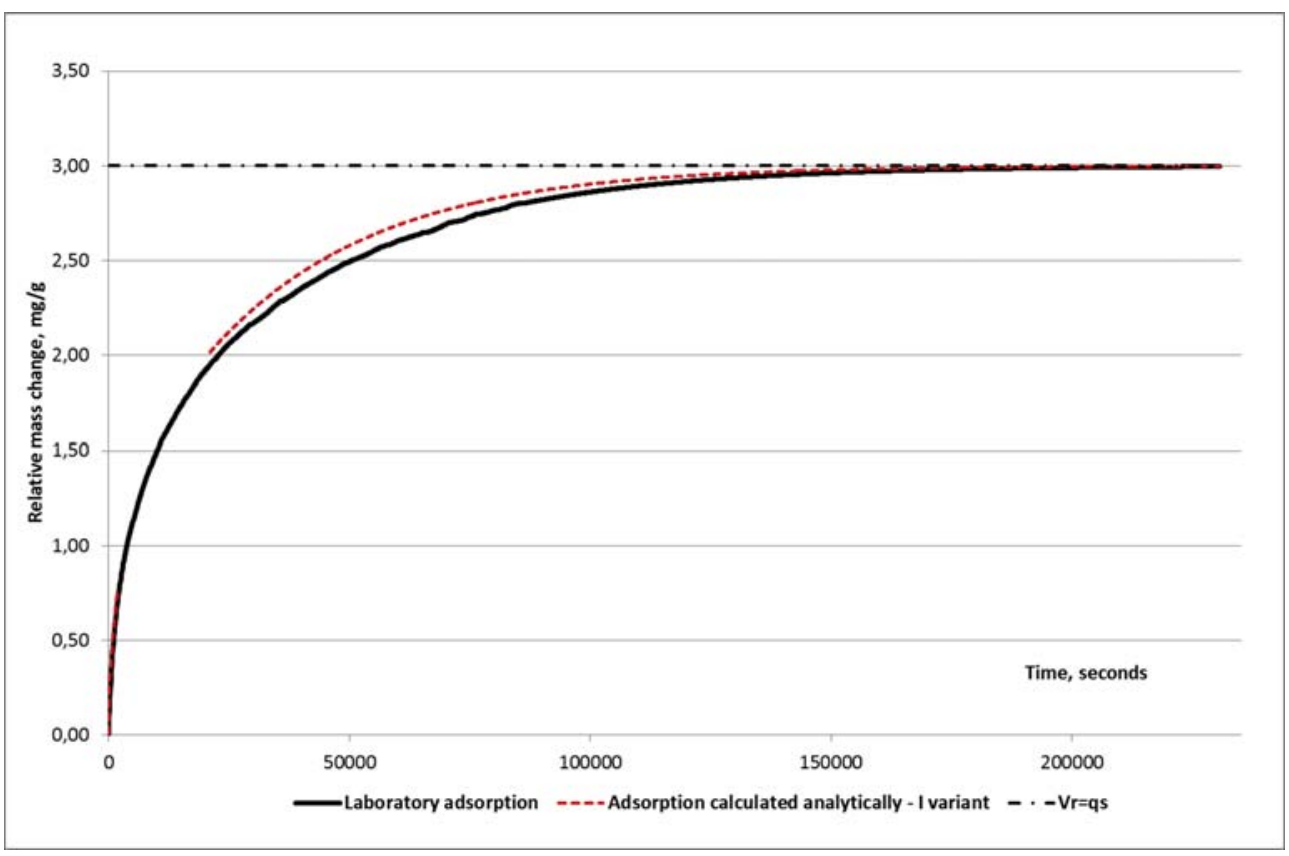

Fig.3. Graph of methane sorption kinetics for the coal sample (seam 404/4 Pniówek coal mine), obtained with laboratory and analytical methods, variant $I$.

The smallest mean relative error ex post was obtained at the value of effective coefficient of diffusion $D_{e}=0.835 \cdot 10^{-9} \mathrm{~cm}^{2} / \mathrm{s}$.

The above comparisons show that the value of coefficient $R^{2}=0.9996$, which corresponds to coefficient $r=0.9998$, also demonstrates nearly full correlation between the results recorded during laboratory tests and the results obtained with the analytical method. In this instance the value of mean relative error became even lower, $\Psi=0.27 \%$.

Taking into consideration all of the facts, it can be concluded that the equations following the assumptions of J. P. Seidle's methane sorption model, based on Fick's second law, accurately describe the phenomenon in both variants of the calculations. In variant II, the value of mean relative error ex post is approximately $84 \%$ lower than in variant $I$, which

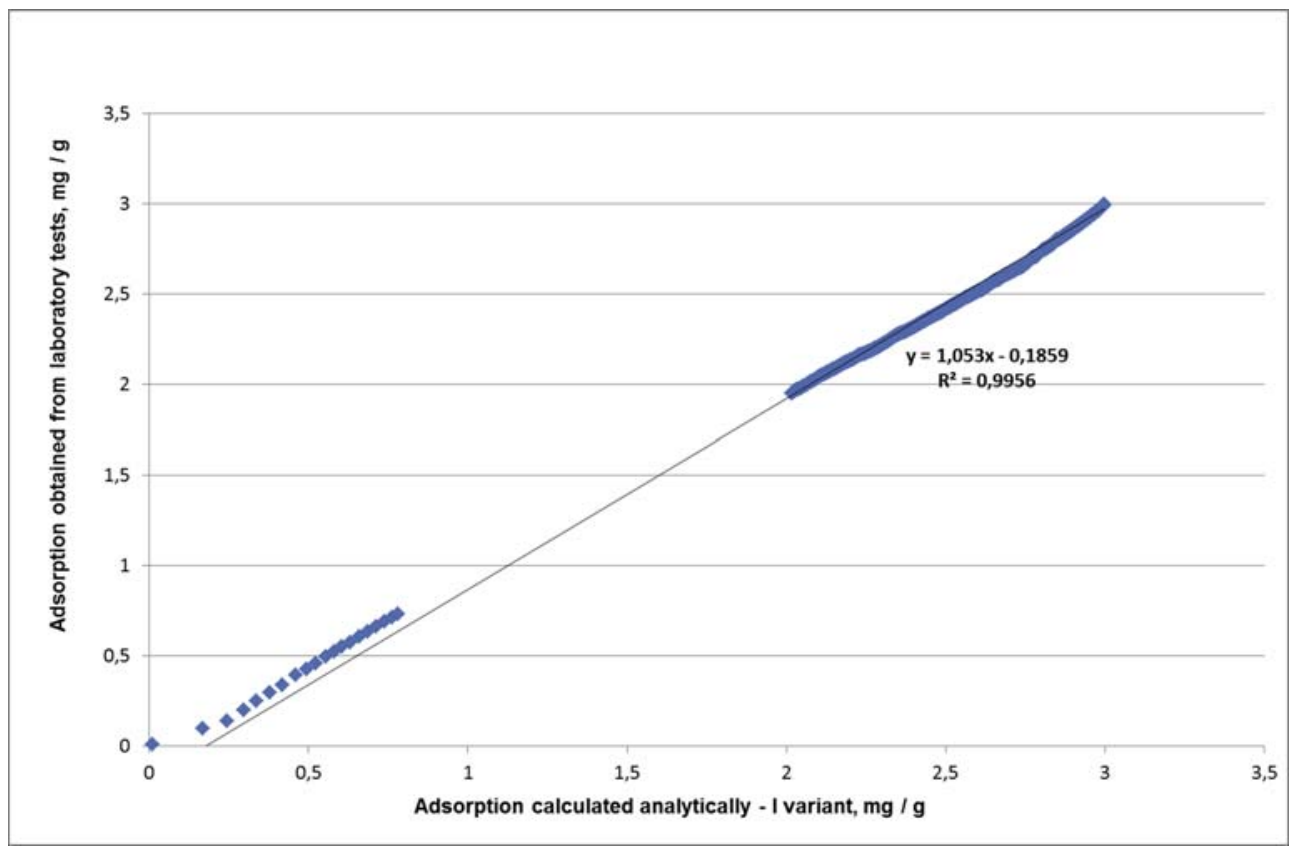

Fig.4. Comparison of methane adsorption courses, obtained with laboratory and analytical methods, variant I. 


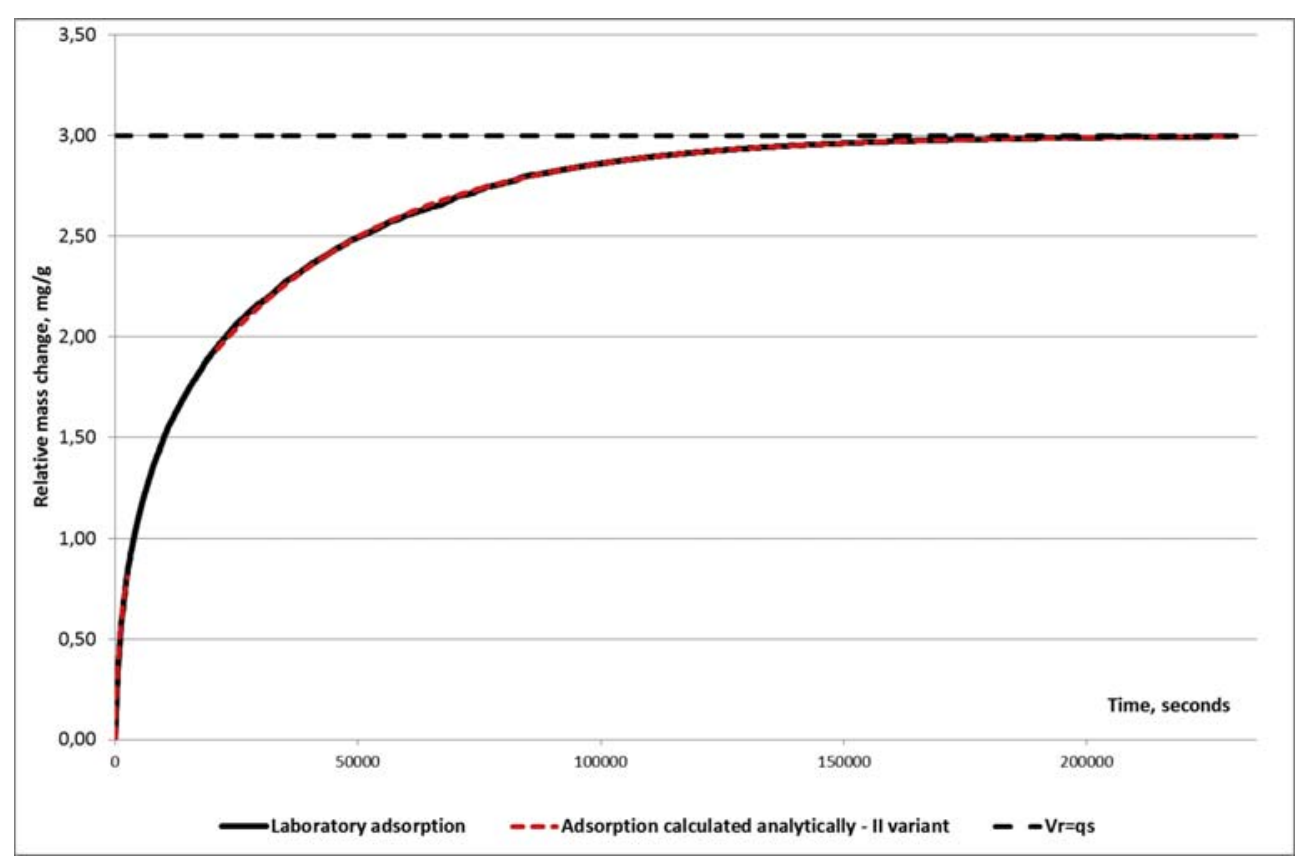

Fig.5. Graph of methane sorption kinetics for the coal sample (seam 404/4 Pniówek coal mine), obtained with laboratory and analytical methods, variant II.

shows that this method of the determination of the effective coefficient of methane diffusion in coal $D_{e}$ is more accurate.

\section{Results and discussion}

1. During mining works in a highly gassy deposit, sorption properties of coal strongly influence the volume and kinetics of methane emission, as shown by the sorption kinetics graphs based on laboratory tests conducted with the gravimetric

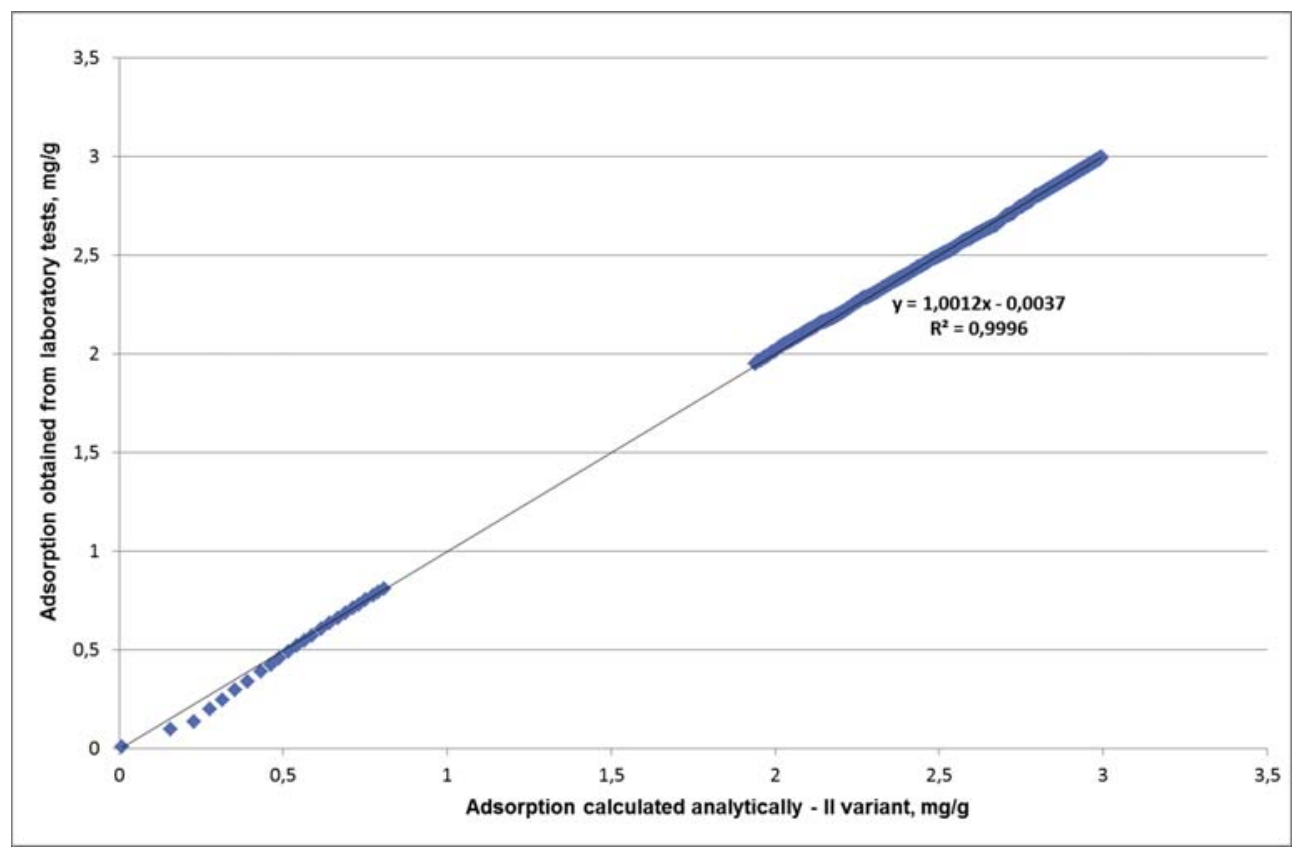

Fig.6. Comparison of methane adsorption courses, obtained with laboratory and analytical methods, variant II. 
and sorption system. To characterise the ability of hard coals to accumulate and release methane, the tests determine the sorption capacity of coal in standard conditions and the value of the effective coefficient of diffusion $D_{e}$.

2. The 2-variant attempt to describe the sorption kinetics graphs with equations which following J.P. Seidle's assumptions of methane sorption kinetics model, based on Fick's second law for the isotropic radial diffusion, shows that the assumptions made for the mathematical model are correct and the model itself describes properly the phenomenon in both variants of calculations.

3. The value of coefficient $D_{e}$, determined as an element which tunes the mathematical model of sorption (variant II of calculations),makes it possible to model the sorption kinetics graph determined in laboratory conditions, better than the value calculated following the Timofeev equation (the value of mean relative error ex post is approximately $84 \%$ lower).

4. Development of more accurate methodology to determine the effective coefficient of methane diffusion in coal also paves the way for further research aimed at the determination of: the gas bearing capacity of coal seams, the degree of the degassing of coal seams as a result of mining operations, or to what extent it is possible to degas deposits.

5. Results of this work will make it possible to obtain more accurate assessments of the possible dynamics of methane emissions during mining operations under methane hazard and gas and rock outburst hazard in hard coal mines.

\section{Conflict of interest}

None declared.

\section{Ethical statement}

Authors state that the research was conducted according to ethical standards.

\section{Funding body}

The research was conducted within the framework of the statutory works of the Central Mining Institute in 2017-2018 and financed by the Ministry of Science and Higher Education (work number: 1105011 7-210).

\section{References}

[1] Busch A, Gensterblum Y, Krooss B, Littke R. Methane and carbon dioxide adsorption-diffusion experiments on coal: upscaling and modelling. International Journal of Coal Geology 2004;60:151-68.

[2] Koptoń H. Metoda prognozowania metanowości bezwzględnej wyrobisk korytarzowych drążonych kombajnami w kopalniach węgla kamiennego. Praca doktorska [Method of prognosing absolute methane content in dog headings driven with heading machine in coal mines. Doctoral thesis. Katowice: Główny Instytut Górnictwa; 2009.

[3] Koptoń H. Określenie zbioru czynników i parametrów mających istotny wpływ na wydzielanie się metanu do wyrobisk korytarzowych drążonych $\mathrm{w}$ kopalniach wegla kamiennego[Determination of factors and parameters which significantly influence methane emission into roadways driven in hard coal mines]. V Konferencja Naukowo-Szkoleniowa - Problemy Współczesnego Górnictwa 2012. Prace Naukowe GIG, Górnictwo i Środowisko 2012;1(1).

[4] Koptoń H. Uwzględnienie własności sorpcyjnych węgla przy prognozowaniu metanowości bezwzględnej wyrobisk korytarzowych drążonych przy użyciu środków strzałowych [Consideration of the sorption properties of coal when forecasting absolute methane bearing capacity of the roadway workings driven by using explosives]. Przegląd Górniczy 2015;71(5):54-60.

[5] Koptoń H. Zagrożenie metanowe przy prowadzeniu robót górniczych $\mathrm{w}$ aspekcie własności sorpcyjnych węgla [Methane hazard while conducting of mining operations in aspect of sorption properties of coal]. Przegląd Górniczy 2017;73(2):39-43.

[6] Kopton H, Skiba J. Consideration of sorption abilities of the coal when forecasting absolute methane emissions into the roadway workings in hard coal mines. In: China International Conference on Coal Mine Methane Recovery and Utilization. Hefei, 29-30.05.2010. Proceedings of 2010 International Symposium on Coal Mine Gas Control; 2010. p. 21-31.

[7] Meng Y, Li Zp. Experimental study on diffusion property of methane gas in coal and itsinfluencing factors. Fuel 2004; 185(2016):219-28.

[8] Skoczylas N. Laboratory study of the phenomenon of methane and coal outburst. International Journal of Rock Mechanics \& Mining Sciences 2012;55:102-7.

[9] Skotniczny P. Dynamic Phenomena in the Air Flow in a Mine Drift Caused by Rock and Gas Outbursts. Archives of Mining Sciences 2009;54(4):827-40.

[10] Wierzbicki M. Changes in the sorption/diffusion kinetics of coal-methane system caused by different temperatures and pressures. Gospodarka Surowcami Mineralnymi 2013;29(4): 155-68.

[11] Wierzbiński K, Krause E. Badaniakinetykisorpcjiwęgli z pokładów zagrożonych wyrzutami metanu i skał [Tests of sorption kinetics in coals of seams under methane and rock outburst hazard]. XIII Międzynarodowa Konferencja Naukowo-Techniczna. Górnicze Zagrożenia Naturalne2006.Głębokość eksploatacji a zagrożenia górnicze. Ustroń,7-10 listopada 2006. 2006.

[12] Dutka B, Wierzbicki M. Wybrane własności węgli w rejonach zagrożonych wyrzutami metanu i skał [Some Properties of Outburst Prone Coals in Upper Silesian Coal Basin, Poland]. Górnictwo i Geoinżynieria. Rok 32. Zeszyt 1. 2008.

[13] Timofiejew DP. Izd. AN. SSSR, Moskwa, 1962, p. 100, (in Russian). 1962.

[14] Benham MJ, Ross DK. Experimental determination of adsorption-desorption isotherms by computer controlled gravimetric analysis. Zeitschrift Für Physikalische Chemie Neue Folge 1989;163:25-32.

[15] Beamish BB, Gamson PD, Johnson DP. Investigations of parameters influencing gas storage and release in Bowen Basin coals. Coalseam Gas Research Institute Technical Report, Dept. of Earth Sciences, James Cook University of North Queensland, CGRI TR 91/4. 1991. p. 120. 
[16] Levine JR. Influences of coal composition on coal seam reservoir quality. A review. Symp. Coalbed Methane Res. Dev. 1992;1. Townsville.

[17] Saghafi A, Faiz M, Roberts D. CO2 storage and gas diffusivity properties of coals from Sydney Basin. Australia International Journal of Coal Geology 2007;70(1-3):40-254.

[18] Wierzbicki M, Murzyn T. Sposób wyznaczania wartości efektywnego współczynnika dyfuzji w niepełnym czasie pomiaru sorpcji [Method of determining the value of the effective diffusion coefficient in part-time measurement of sorption]. PraceInstytutu Mechaniki Górotworu PAN 2014; 16(1-2):93-101.

[19] Skoczylas N, Topolnicki J. The coal-gas system - the effective diffusion coefficient. International Journal of Oil Gas and Coal Technology 2016;12(4):412-24.

[20] Koptoń H. Czynniki geologicznogórniczeiparametryorganizacyjno-technicznewpływającenawydzielaniesięmetanu do drążonychwyrobiskkorytarzowych w kopalniach węgla kamiennego [Geological and mining factors, and organizational and technical parameters affecting the emission of methane into the road-ways being driven in hard coal mines]. Wiadomości Górnicze 2011; 62(12):693-700.

[21] Wrona B. Metoda wagowa badania własności sorpcyjnych węgli kamiennych [Weightmethod of testing sorption properties of hard coals]. Przegląd Górniczy 1983;2.

[22] Olajossy A. Relacja: laboratorium - in situ w badaniach desorpcji metanu $\mathrm{z}$ pokładów węgla (Laboratory - in situ relation in tests of methane desorption from coal seams). Zeszyty Naukowe AGH, Kraków: Akademia Górniczo-Hutnicza im. Stanisława Staszica. 1993.

[23] Thimons EP, Kissell FN. Diffusion of Methane Through Coal. Fuel. 1973.

[24] Kolesar JE. Nature of Sorption and Diffusion Phenomena in the Micropore Structure of Coal. SPE; 1986.

[25] Kärger J, Ruthven DM. Diffusion in Zeolites and Other Microporous Solids. New York: Wiley \& Sons; 1992.

[26] Bobok D, Besedová E. Error in the Estimation of Effective Diffusion Coefficients from Sorption Measurements. May 22-26 Proc. 27th Int. Conf. SSChE, Tatranské Matliare, Slovakia. Chem. Papers 2000;54(6b):482-8.

[27] Azimi A, Mirzaei M. Determination of effective diffusion coefficient of methane adsorption on activated carbon. World Applied Sciences Journal 2012;17(9):1109-14.

[28] Metcalfe RS, Yee D, Seidle JP, Puri R. Review of Research Efforts in Coalbed Methane Recovery. Workshop on the Recovery and End - Use of Coal - Bed Methane. Report no. A-10, Katowice. 1992.

[29] Seidle J. Fundamentals of Coalbed Methane Reservoir Engineering. PennWell Books; 2011.

[30] Crank J. The Mathematics of diffusion. $2^{\text {nd }}$ ed. London: Oxford Univ. Press; 1975. p. 414.

[31] Pillalamarry M, Harpalani S, Liu S. Gas diffusion behaviour of coal and its impact on production from coalbed methane reservoirs. International Journal of Coal Geology 2011;86(4): $342-8$. 